\title{
Real and Monetary Convergence within the European Union and Between the European Union and Candidate Countries: A Rolling Cointegration Approach
}

\author{
By: Josef C. Brada, Ali M. Kutan and Su Zhou \\ William Davidson Working Paper Number 458 \\ April 2002
}




\title{
Real and Monetary Convergence within the European Union and Between the European Union and Candidate Countries: A Rolling Cointegration Approach
}

\author{
Josef C. Brada \\ Department of Economics, Arizona State University, Box 873806, Tempe, AZ 85287-3806 U.S.A. \\ Tel: 480-965-6524 Fax: 480-965-0748 \\ josef.brada@asu.edu
}

\begin{abstract}
Ali M. Kutan
Department of Economics and Finance, Southern Illinois University at Edwardsville, Edwardsville, IL 62026-1102, USA

Tel: (618) 6503473 Fax (618) 6503047

and

Center for European Integration Studies, Bonn

akutan@siue.edu

Su Zhou

Department of Economics, University of Texas at San Antonio, San Antonio, TX 78249-0633. Tel.:

(210) 458-5398; fax: (210) 458-5837.

szhou@utsa.edu

Abstract

We use rolling cointegration to measure the convergence of base money, M2, the consumer price index and industrial output between two reference countries, Germany and France, and recent EU members and some transition economy candidates. Counties that recently joined the EU exhibit time-varying cointegration with the reference countries over much of the 1980-2000 sample period. Cointegration for the transition economies was comparable for M2 and prices, but less so for monetary policy and industrial output. This suggests that a peg to the Euro upon accession is feasible for the East European candidates, but the benefits of joining the Euro zone are as yet limited.
\end{abstract}

JEL Classification Numbers: F 15, F 36, F 42

Key words: European Union, convergence, currency areas, enlargement, cointegration, policy coordination 


\section{INTRODUCTION}

In this paper we examine the time-varying character of the cointegration between financial and real macroeconomic aggregates of the European Union (EU), proxied by the Federal Republic of Germany and by France, of countries that have recently joined the EU and of the transition countries that are candidates for EU membership. The imminence of the accession to European Union membership of the current group of "leading" or "firstround" transition and market economy candidate countries as well as the growing credibility of the candidacy of some of the "second-round" transition economy candidates has given rise to a growing literature on convergence between these candidate countries and the European Union. ${ }^{1}$

This paper contributes to the discussion of intra-EU and transition economy-EU convergence in two ways. First we utilize the technique of rolling cointegration to obtain time-varying estimates of the convergence of macroeconomic variables within the EU and between transition economies and the EU. Second we use measures of both monetary and real convergence. The former includes a measure of monetary policy, the growth of base money, as well as M2 and the consumer price index (CPI), measures of monetary policy outcomes . We examine real convergence by investigation the cointegration of industrial output data.

In the next section, we examine the concept of convergence as it has been used in the literature on EU accession, explain why convergence in its various forms is important, and briefly review the literature on this topic. In section III we explain the rolling cointegration methodology employed in this paper and describe the data we use for our tests

\footnotetext{
${ }^{1}$ In this paper we confine ourselves to the first round transition-economy candidates, the Czech Republic, Estonia, Hungary, Poland, and Slovenia.
} 
of convergence. Section IV contains the results, and section V draws the policy implications from the empirical findings.

\section{MEASURING CONVERGENCE: REVIEW OF THE LITERATURE}

Why convergence should be such an important issue depends in part on how convergence is conceived and measured and in part on which variables' convergence is at issue. One strand of the convergence literature is based on the concept of the optimal currency area (Mundell, 1961). It reflects the fact that, although EU accession does leave new members considerable leeway in choosing the strength of the link between their national currencies and the Euro, both the current exchange rate regimes and policy pronouncements of the front-runner candidate countries as well as a host of political and economic considerations suggest that these countries will opt to peg to the Euro, if not before accession then shortly thereafter (McKinnon, 1999). Some time after accession, of course, these new members are expected to join the Euro zone. The convergence literature based on optimal currency area theory therefore seeks to determine whether these prospective EU members and the current Euro zone countries would, indeed, form an optimal currency zone.

Empirical efforts to establish whether the EU members themselves meet the conditions for an optimal currency area, such as the seminal paper by Bayoumi and Eichengreen (1993), form the methodological basis of much of this work on convergence and provide benchmark results against which the convergence of the transition-economy candidates can be judged. Bayoumi and Eichengreen tested whether EU members displayed sufficient correlation of their supply (real) and demand (monetary) shocks over the period 1960-1988. Supply shocks were extracted from GDP data and demand shocks from aggregate price indices. The authors found that their sample of EU member countries 
divided into a core group for which the magnitude and correlations of shocks seemed to meet the criteria for the existence of an optimal currency area and a group of outsider countries for whom the correlation of shocks with the core group was so weak as to suggest that the conditions for their participating in an optimal currency area made up of the core countries were not met.

These findings were updated and extended by Korhonen and Fidrmuc (2001) who found that, on the basis of data for 1991-2000, a number of the countries that had failed to meet the convergence criteria for membership in an EU-based optimal currency area during Bayoumi and Eichengreen's sample period now displayed considerably more convergence and could be considered as potential members of an EU optimal currency area. This finding is important for the methodology used in this paper because it highlights the time-varying nature of convergence, which Korhonen and Fidrmuc rightly view as an evolving rather than a static concept. Korhonen and Fidrmuc applied the identical methodology to the transition-economy countries who are candidates for EU membership, and they found that, while the correlations of the real shocks of Hungary and Estonia are of an order of magnitude comparable to intra-EU levels, the other transition economies display much lower levels of correlation. One drawback of the exercise is the short sample period, 1994 or 1995 to 2000, which was imposed on the authors by their reluctance to use data that cover the period of the sharp output decline that marked the early years of the transition period.

A pervasive characteristic of studies like those of Bayoumi and Eichengreen (1993) and Korhonen and Fidrmuc (2001) that examine both supply (GDP) and demand (inflation) shocks simultaneously is that the former indicator yields results that are considerably more significant and easy to interpret than does the latter. Consequently, a number of researchers 
have focused exclusively on correlations in the business cycle, as measured by GDP or industrial output, and ignored inflation measures altogether. Some of these studies, such as Estrin et al. (2001) and Kočenda (2001) come to divergent conclusions. The former study finds no convergence for transition economies either with each other or with the EU countries for the period 1970-1998 while the latter finds the existence of cointegration of industrial output at least among some of the transition economies. Such divergent conclusions, often resulting from differences in the length of the sample period, are also evident in previous studies that focus exclusively on the convergence of real measures of economic activity of the transition economies with those of the EU countries, as the survey of this literature provided by Korhonen and Fidrmuc (2001) clearly shows.

Whatever the conclusion of the foregoing studies of convergence is, their location in the optimal currency area framework gives them both a normative and a positive aspect. If a candidate country's supply and demand shocks are closely correlated with those of the Euro-zone countries, then it should be beneficial for that country to join the Euro zone. It will gain the benefits of lower transactions costs in trade and investment with other members of the Euro zone, and the costs of following Euro-zone wide monetary and fiscal policies will be low due to the similarly of the shocks affecting it and the other members of the optimal currency area. Thus, an early peg to the Euro and quick adoption of the Euro as a national currency would be welfare enhancing for the candidate country. These findings can also be interpreted from a positive perspective in that a failure to meet the criteria for belonging to the Euro optimal currency area will impose high costs in reduced policy autonomy that will outweigh the benefits of reduced transactions costs, and this disparity between costs and benefits may cause the accession countries to backslide on their 
commitments to a stable relationship between their currencies and the Euro and, indeed, to eventual membership in the Euro zone.

The second strand of the convergence literature also draws on an older literature, that dealing with the performance of the European Monetary System (EMS). Starting with the early 1990's, a number of studies, of which von Hagen and Fratianni (1990) and Kirschgössner, and Wolters (1993) are instructive examples, sought to determine whether the members of the EMS could in fact maintain the necessary currency pegs by following similar macroeconomic policies. Usually, the test of this hypothesis was framed in the convergence between the monetary policies of various EMS countries and of the Federal Republic of Germany. The existence of cointegration between the series, rather than the correlation of shocks, served as a test of the convergence hypothesis. The rationale was that the Bundesbank had the most credible monetary policies in the EMS, and, thus, if other currencies were to remain at a fixed parity against the Dm, then the central banks of these other EMS member countries would have to allow their policies to converge to, or, in the parlance of this literature, to be dominated by, those of the Bundesbank. One issue unresolved by this literature was whether convergence was to be sought in measures of monetary policy, such as the growth of base money or the interest rate, or in terms of the outcomes of monetary policy such as the rate of inflation.

Using cointegration as a measure of convergence, Kočenda (2001) found weak or nonexistent convergence of financial variables among transition economies in the 1990s. Also using cointegration, Brada and Kutan (2001) observed strong convergence between the growth of base money in Germany and in the countries that recently joined the EU as well as in the current market-economy candidates for EU membership. In contrast, the transition-economy candidates displayed no cointegration with German base money 
growth. These negative findings for the transition economies say nothing about the desirability of the transition-economy candidates adopting an early peg against the Euro and joining the Euro zone, but they do raise questions of the feasibility of doing so. If these countries prove unable to maintain a level of macroeconomic discipline consistent with a peg to the Euro, then whatever the benefits of being in a Euro-centered optimal currency area may be, the transition economies will be unable to remain a part of it for long.

The studies of transition-economy convergence to German monetary policy also suffer from a number of shortcomings. The first of these is that the time period examined covers disparate situations such as the transition recession, stabilization and then recovery and conscious efforts to prepare for EU membership. Consequently, the degree of convergence to German monetary policy should change considerably over time, a point already raised above with respect to the optimal currency area literature. The second problem is that, particularly for transition economies, it is difficult to determine which variable should be used to measure convergence. For example, Brada and Kutan (2001) focused on cointegration between base money in the candidate countries and in Germany because they assumed that other monetary variables in the transition economies were poor measures of monetary policy due to changes in the transmission mechanism from monetary policy to outcomes caused by financial sector reform and by factors peculiar to transition economies such as price convergence to the EU and large Balassa-Samuelson effects.

Financial sector reform and deepening in the transition economies are important because they alter the relationship between monetary policy and its outcomes. Thus, even if the transition economies were to follow the monetary policies of the Bundesbank or, now, the European Central Bank (ECB), major changes in their financial systems could transform such policy into quite different results in terms of the growth of broader measures of the money 
supply, interest rates or inflation. Thus, in preparing for EU membership, it is difficult to decide whether their central banks should seek to follow ECB policies by following similar growth rates for their stock of base money or whether they should frame their policies to yield the results in terms of inflation or broad money measures being obtained by the ECB. The practical implication of this argument for research is that we need to examine not only the cointegration between EU and transition-economy base money growth, but also the cointegration of the growth of broader money aggregates and of prices as well. Janáčková (2000) and Richards and Tersman (1996) examine the issue of price-level convergence between the EU and the transition-economy candidates. They point out that the transition economy candidates for EU membership have lower price levels than do existing EU members and that the gap is quite large. In part this gap in the level of prices exists between most countries whose income levels differ by as much as do those of the current EU members and the current group of candidate countries. In the case of the transition economies, low price levels are also a legacy of the former economic system, which artificially repressed prices, and of current policies in these countries that liberalize controlled prices only slowly. The economic significance of this price level convergence is that such a process necessarily implies higher rates of inflation in the candidate countries that in the current EU zone, thus perhaps limiting our ability to observe effective convergence of inflation rates.

In this paper we seek to advance the discussion of transition economy-EU convergence in two ways. First, we utilize the technique of rolling cointegration to obtain time-varying estimates of the convergence of transition economy and EU macroeconomic variables. If the candidate countries were in the process converging with the monetary policy of Germany and France or the ECB during this period, then a test for convergence having been achieved over the entire sample, such as provided by conventional tests for 
cointegration, would be biased toward rejecting cointegration and thus convergence. We overcome this possibility by using rolling cointegration tests that explicitly take into account the possibility that the data series are (more) integrated during some parts of the sample period but less so or not at all not during other parts. Moreover, the use of rolling cointegration allows us to use a longer time period and to test for evidence of cointegration early on in the transition without fear that these early data will bias tests for cointegration later years. $^{2}$

The second area of advance is to be found in our use of a measure of monetary policy, the growth of base money, as well as measures of monetary policy outcomes such as the growth of M2 and the consumer price index (CPI). By using both a variable that captures monetary policy and two variables that reflect the outcomes of monetary policy we can determine whether the transition economies have reached a stage in the development of their financial systems that would allow them to follow the policies of the ECB and achieve the same types of policy outcomes as obtained by EU member countries. We also examine real convergence by investigation the cointegration of EU and transition-economy industrial output data. Thus we are able to address both the desirability of the transition economies drive for an early entry into the Euro zone on optimal currency area grounds and their ability to sustain that participation through the necessary macroeconomic policies.

\footnotetext{
${ }^{2}$ While it would be surprising to find evidence of cointegration of industrial output between the EU and transition economies in the early years of the transition, most of the transition economies did peg to western currencies in the early 1990s, and, thus, some financial cointegration may be expected.
} 


\section{METHODOLOGY AND DATA}

\section{A. METHODOLOGY}

We use cointegration analysis to investigate the convergence of the nonstationary monetary and real data of the sample countries. The time series of several variables, $\mathrm{X}_{\mathrm{t}}$, are cointegrated if these variables are individually nonstationary but there exists at least one linear combination of them that is stationary. Such cointegrated variables cannot drift apart, and thus they have achieved a measure of convergence. However, the condition of having achieved convergence is quite different from that of achieving convergence. If a system of variables is achieving convergence, that is, moving from an un-cointegrated state to one that is characterized by the existence of cointegration, then the underlying probability law is in flux because either its parameters or stochastic properties are changing. Traditional tests for the presence of cointegration over the entire sample period would thus tend to reject the hypothesis that the series are cointegrated if the extent of cointegration changes over time. Also, because the change is gradual, tests for structural breaks in the model are likely to reject the hypothesis of a structural break. Consequently, to deal with this possibility of gradually time-varying cointegration, we use rolling cointegration, a technique that explicitly allows for changes in the relationship between a system of variables. $^{3}$

We use the rolling cointegration tests to investigate the degree of convergence during different sub-sample periods of the full sample using the cointegration rank tests of Johansen $(1988,1991)$. The Johansen tests use the following vector autoregressive (VAR) system:

\footnotetext{
${ }^{3}$ Specifically, we apply the techniques used by Hansen and Johansen (1999) and Rangvid and Sørensen (2000), whose description of the technique we follow here.
} 


$$
\Delta \mathbf{X}_{t}=\sum_{j-1}^{k-1} \Gamma_{i} \Delta \mathbf{X}_{t-j}+\Pi \mathbf{X}_{t-1}+\mu_{0}+\epsilon_{1}
$$

where $\mathrm{X}_{\mathrm{t}}$ is a vector of $n$ variables, $\mu_{o}$ is a constant term, and $\varepsilon_{t}$ is a vector of independent Gaussian variables with mean zero and variance matrix $\Sigma$. The relevant hypotheses have to do with $\Pi$; if the rank of $\Pi$ is $r$, where $r \leq n$-1, then $\mathrm{r}$ is called the cointegration rank. By including $\mu_{o}$ in the model of $\Delta \mathrm{X}_{t}$, equation (1) allows a linear time trend to be present in the DGP of $X_{t}$.

Regressing $\Delta \mathrm{X}_{t}$ and $\mathrm{X}_{t-1}$ on $\Delta \mathrm{X}_{t-1}, \ldots, \Delta \mathrm{X}_{t-k+1}$, and one yields residuals $R_{0 t}$ and $\mathrm{R}_{1 \mathrm{t}}$ and residual product matrices:

$$
S_{i j}=\mathrm{T}^{-1} \sum_{t-1}^{T} R_{i t} R_{j t}, \quad i, j=0,1
$$

We then solve the eigenvalue system

$$
\left|\lambda S_{11}-S_{10} S_{00}^{-1} S_{01}\right|=0
$$

for eigenvalues $\hat{\lambda}_{1}>\ldots>\hat{\lambda}_{n}$ and eigenvectors $\hat{V}=\left(\hat{v}_{1}, \ldots, \hat{v}_{n}\right)$. The trace statistic for the null hypothesis of at most $r$ cointegration vectors is:

$$
\operatorname{Trace}(r \mid n)=-\mathrm{T} \sum_{j=r+1}^{n} 1 n\left(1-\tilde{\lambda}_{j}\right)
$$

The asymptotic distribution of the trace test statistic is derived in Johansen and Juselius (1990), and the corresponding critical values are presented in Osterwald-Lenum (1992).

The rolling cointegration tests are conducted by setting $\mathrm{k}=4$ and rolling monthly 5 year sub-samples, using $60+\mathrm{k}$ observations with the effective number of observations thus equal to 60 through the full sample. ${ }^{4}$ Using a bivariate approach, the tests are applied to

\footnotetext{
${ }^{4}$ The residuals from the models with $\mathrm{k}=4$ are not significantly serially correlated.
} 
the variables of Germany or France and of each candidate country. ${ }^{5}$ The first trace test statistic is obtained by using a total of $60+\mathrm{k}$ observations from the beginning of the sample period through to the 64th observation, for example, January 1990 - April 1995. The next test statistic is obtained by using data from the second observation through to the 65 th observation, and so on, until the last observation was used. Because the sample size that we employ is rather small, the asymptotic critical values of the Johansen trace test are adjusted by a factor of $\mathrm{T} /(\mathrm{T}-n k)$ where $\mathrm{T}$ is the effective number of observations, as suggested by Reinsel and Ahn (1992). ${ }^{6}$ The trace statistics obtained from the rolling cointegration tests are scaled by the adjusted critical values at the $10 \%$ significance level and plotted in the Figures reported in Section IV. A value greater than 1 for this series indicates rejection of the hypothesis of no cointegration.

\section{B. $\underline{\text { DATA }}$}

Because we wish to examine both monetary and real convergence and because we are interested in seeing whether the transition economies' measures of economic policy as well as the outcomes of monetary policy and also industrial output are cointegrated with the corresponding series for the EU, we examine the behavior of several macroeconomic aggregates. We use the monetary base as our measure of monetary policy because it is the variable most directly under the control of the monetary authorities. The CPI and broad

\footnotetext{
${ }^{5}$ We do not apply the unit root tests to examine the order of integration (nonstationarity) for individual variables, because the Johansen cointegration rank tests can be used not only to test for the long-run relations among the integrated variables but also to identify the order of integration of the variables in the system. For example, for a bivariate system $\left[\mathrm{x}_{1 t}, \mathrm{x}_{2 t}\right]$, the finding of the cointegration rank to be two would suggest that the two variables are integrated of order zero (i.e., stationary). If there is no indication of cointegration, the two variables are nonstationary. In case one cointegrating vector exists, and if the coefficients of all the variables in the vector are statistically significant, it would be evidence that these variables are individually nonstationary and they are cointegrated. If the cointegration coefficient of $\mathrm{x}_{1 t}$ is significant but that of $\mathrm{x}_{2 t}$ is not, it would indicate that $\mathrm{x}_{1 t}$ is stationary. In our cases of rolling bivariate cointegration, we found that the variables that we deal with are either not cointegrated or cointegrated with the rank being one and with both variables being statistically significant in the cointegrating vector.
} 
money (M2) are our proxies for the outcomes of monetary policy, and industrial output provides a measure of real sector activity. We examine three groups of countries. The first group consists of Germany and France, which serve as our benchmarks of EU policy and macroeconomic performance. Germany is the country traditionally used for this purpose in the convergence literature because of the alleged credibility of the policies of the Bundesbank and because it is the largest economy in the EU. Moreover, it is the largest trading partner of the transition economies. However, Germany experienced considerable monetary and real turbulence in the early and mid-1990s due to the difficulties encountered in the reunification of the country. Consequently, we also use France as a benchmark as it did not experience the adjustment costs that Germany did, and thus it may serve as a more stable indicator of EU policies and performance.

The second group consists of countries that have more or less recently become members of the EU, and it includes Austria, Denmark, Portugal, Spain, and Sweden. We use these countries and a long sample period going back to 1980 in order to examine the degree of cointegration that these countries exhibited before and after their entry into the EU, thus providing us with a benchmark by which to judge the results for the transition countries. In the final group we include the first round candidates: the Czech Republic, Estonia, Hungary, Poland, and Slovenia.

Monthly data are employed for all estimations. ${ }^{7}$ The sample period for the recent EU members generally covers the 1980-2001 period while for the rest of the countries the data begin in early 1990s and run through 2000 or 2001. Specific sample periods for each

\footnotetext{
${ }^{6}$ Using a bootstrapping technique, Giersbergen (1996) shows that the asymptotic critical values adjusted by such a factor fit the finite-sample cointegration studies quite well.

${ }^{7}$ All the data are seasonally adjusted using the multiplicative exponential smoothing method. The adjustments are made using RATS (version 3.12) with the command: esmooth(trend=exponential,seas $=$ mult,smooth $=\mathrm{xxx}$ ) yyy

where $x x x$ is the name of output series, yyy is the name of the series to be adjusted.
} 
group of countries are given in Table 1. All data are taken from the IMF International Financial Statistics CD Rom.

\section{RESULTS}

The tests of the hypothesis that the series are not cointegrated are reported in Figures 1-4. Each Figure reports rolling cointegration tests for a specific variable such as industrial production, the money stock, etc., and each Figure has four panels. The first panel shows the significance test for cointegration between the German series and those of the recent EU members. The second panel provides the same formation but with France rather than Germany as the reference country. Note that these panels cover the period 1985-2001 as the sample period for these countries begins in $1980 .^{8}$ Panel three provides the significance tests for cointegration between the transition economies and Germany for the same variable, while panel four reports the same information with France as the reference country. Because the transition-economy data begin in the early 1990s, these panels provide test statistics for 1995 to 2001. In each panel we report the test statistic divided by the critical value at the $10 \%$ significance level. Thus, a value above one means that the test statistic rejects the hypothesis of no cointegration at the specified significance level. The test statistic is reported on the last month of the rolling five-year sample period from which it is derived, and, consequently, a value greater than one reported for, say, December 1999 means that we can reject the hypothesis that the two series in question were not cointegrated for the period of 60 months up to and including December 1999.

Figure 1 reports results for base money, our indicator of monetary policy. The first panel shows that from 1985 until the early 1990s the test static scaled by the $10 \%$ critical

\footnotetext{
${ }^{8}$ The series for the recent EU members cover a longer time period in order to capture the convergence these countries achieved prior to, or shortly after, their accession to membership. Of course, the degree of
} 
value exceeds one for many of the EU member countries, indicating the convergence of these countries' monetary policies with that of Germany from 1980 to $1992 .{ }^{9}$ The scaled test statistics associated with the sample periods ending in 1992-1997, with the exception of Denmark, are generally less than one, suggesting that, over the corresponding sample periods, cointegration between German and sample countries' base money series can be rejected. In view of the cointegration evident in years previous to this period, the early and mid-1990s turbulence in the EMS and from Germany's reunification efforts are likely responsible for this result. In the late 1990's the scaled test statistic rises again, reflecting the effects of policy integration brought about by the Maastricht process. The second panel of Figure 1 reports the same results but with France as the reference country. The results for France mirror those for Germany in that there is evidence of convergence early on, but there is a somewhat briefer lapse in cointegration in the mid-1990s and then an increase in convergence for some EU members in the late 1990s. To sum up, the evidence for those countries that have recently joined the EU is that that base money series were cointegrated with those of Germany and France for significant periods in the 1980s before these countries joined the EU and after, especially toward the end of the sample period. Nevertheless, there are periods of time, especially in the mid-1990s, when some or all of the recent EU members' monetary policy, as measured by base money stock, was not

\footnotetext{
convergence achieved in the 1980s, for example, also depends on the economic and institutional environment of that period, which differed in important respects from that of the 1990s.

${ }^{9}$ Recall that the scaled test statistic is reported on the last month of the 60 -month rolling sample period. Thus a value greater than one in 1985 means that we cannot reject cointegration for a sample covering 1981-85.
} 
cointegrated with either that of Germany or of France. A final conclusion drawn from these results that applies to the results reported in subsequent Figures is that there is no systematic difference in the cointegration pattern of the EU members who joined in the 1990s and those who joined in the earlier expansion of the EU.

The third and fourth panels report the test statistic for cointegration between the transition economy candidates and Germany and France respectively. In the case of Germany, cointegration of Polish and Slovenian base money is clearly evident for the 5 year periods ending with the financial crises of 1997, when the East European countries were hit by contagion from the Russian crisis. Subsequent to that period, only Poland's base money series exhibits cointegration with that of Germany. The other transition economies display little if any cointegration with Germany. This is particularly surprising in the case the Czech Republic, which maintained de facto or de jure fixed rates vis a vis the Dm over much of the sample period. In the case of Estonia, with its currency board, this result is less surprising. Panel 4 reveals stronger cointegration between the transition economies and France, as all countries save the Czech Republic achieve cointegration by the end of the sample period. Also noteworthy is that Poland exhibits cointegration for the early transition period of 1991-1995, both against Germany and France.

Given the evidence of at least periodic cointegration of base money series for Germany, France and the recent EU member countries, the results of Figure 2, showing the cointegration of these countries' M2 series, are not surprising because the base money series are indicators of central bank policy while M2 can be seen as the outcome of that policy. Indeed, if anything, the M2 series show higher levels of cointegration and more sustained cointegration than do the series in Figure 1. There is also a strong effect of proximity on the degree of cointegration achieved by individual countries. Thus Sweden, Denmark and, later 
in the sample period, Austria, show strong cointegration of their M2 series with that of Germany. Portugal and Spain, on the other hand, exhibit strong cointegration with France. This tendency for countries that are close to each other to be effected by similar shocks was also noted by Bayoumi and Eichengreen (1993) and Korhonen and Fidrmuc (2001) especially with respect to shocks to GDP . Our results suggest that this proximity effect carries over to monetary aggregates in EU member countries as well.

The transition economies also show somewhat stronger cointegration for M2 than they do for base money. For example, Estonia and the Czech Republic, which showed little or no cointegration with German base money exhibit cointegration for M2. This may be due to the fact that there is considerable direct lending to firms in these two countries as well as other capital flows from Germany and these inflows show up in Czech and Estonian M2. Thus cointegration of M2 between these countries and Germany would be expected if these capital flows respond to M2 movements in Germany. The lack of cointegration of Czech base money with the German series may then reflect efforts on the part of the Czech National Bank to sterilize these capital inflows to some extent. ${ }^{10}$ France's M2 series shows cointegration with that of Poland for much of the sample period save the 1998-1999 period as well as stretches of cointegration for Hungary and also Slovenia late in the sample.

Figure 3 reports tests of cointegration for the consumer price index (CPI) of the sample countries. The CPI reflects the effects demand shocks, many of which are, of course, the consequences of changes in monetary policy. Movements in CPI are, however, even more intensively transmitted from country to country through trade channels than are movements in M2 through capital flows. This helps to account for the results reported in the first panel of Figure 3. German CPI is cointegrated with that of the recent EU members for

\footnotetext{
${ }^{10}$ For some discussion of Czech monetary policy in this regard, see Begg (1998).
} 
much of the sample and the movements in the test statistics are similar for all the countries in the sample. In the second panel, the CPIs of France and the EEU members are also cointegrated for appreciable periods of time, although the pattern varies from country to country more than is the case for German CPI. Moreover, proximity continues to play a role, with Austria and Sweden displaying a particularly consistent record of cointegration with Germany, and, in the second panel, Spain and Portugal are more consistently cointegrated with French CPI than are the other countries.

Panels 3 and 4 report the test statistics for the EU candidate countries, and the results parallel those for EU members. Cointegration of CPI for the candidate countries exceeds that observed for base money or M2. Poland, for example, achieves cointegration with German CPI for almost the entire sample period, and the other countries achieve it for about half the sample period. Much the same can be said for the case of French CPI.

Our final set of cointegration tests concerns industrial production, a real, or supply shock, variable. The first two panels suggest that real convergence among the EU countries as measured by the cointegration of industrial production, does not appear much stronger than is the convergence of monetary policy or outcomes, that is, the demand shock variables. In the case of Germany, Austria and, to a lesser extent, Denmark and Spain exhibit some cointegration. Sweden on the other hand displays almost none. Cointegration with France appears to be marginally stronger for some of the countries. Austria again fares best, followed by Spain and Denmark, but Sweden is about as uncointegrated with French industrial production as it is with German. In the case of the transition economies, Hungary displays almost no cointegration with either Germany or France. With the exception of Slovenian cointegration with Germany and of Czech cointegration with both reference 
countries in the latter part of the sample, real cointegration for the transition economies is much less than was evident for the recent EU members. ${ }^{11}$

\section{POLICY IMPLICATIONS AND CONCLUSIONS}

In this paper we have used Germany and France as proxies for the EU macroeconomy to examine the extent to which recent EU members and transition economy candidates for EU membership are cointegrated with the EU and with the Euro zone. The cointegration of real variables, in our case, industrial production, determines whether these countries are subject to similar supply-side shocks and thus are suitable members of an optimal currency area that includes the core countries of the EU. Cointegration of monetary aggregates provides evidence regarding the feasibility of a peg between the currencies of the new members and the Euro.

Before we turn to specific conclusions and their implications for accession policies for transition economies, we offer some more general conclusions. The first is that, although we found some differences in the pattern of cointegration between our sample of EU and transition economies and France and Germany, either of these two latter reference countries yielded qualitatively similar conclusions. Clearly the period of the mid-1990s saw lower levels of cointegration between Germany and the other countries than between France and the same countries, using either country as a proxy for the EU economy is acceptable. The only caveat to this conclusion is that, like previous studies of the suitability of EU countries for an optimal currency area, we found significant evidence of the effect of proximity on the cointegration of countries' real and monetary time series. Finally, our results show that cointegration, even among EU members, varies in intensity over time. EU

11 The finding of no cointegration for Hungary is particularly surprising in light of Korhonen and Fidrmuc's (2001) finding that Hungary had one of the highest transition-economy correlations of real shocks with the EU. 
members' cointegration with the two core countries was already evident in the 1980s, weakened considerably in the mid-1990s, and then strengthened at the end of the 1990s. Thus, the time period over which the correlation or cointegration of shocks is measured can significantly influence the outcome of such exercises.

For both the recent EU members and the transition-economy candidates, the intensity of cointegration increased as we moved from base money to M2 and to the CPI. These results suggest that the coordination of monetary policy as measured by base money movements is not the only, or perhaps not even the prime, means of coordinating money supply growth and inflation in the Euro zone and the transition economies. In the case of M2, even if smaller transition economies with weak capital markets follow different base money policies, large countries such as Germany can still influence their M2 growth through captal flows that cannot be entirely sterilized. This cointegration is even more evident in the case of prices as measured by the CPI, not only for transition economies but also for the recent members of the EU. We hypothesize that this result is largely due to the ability of international trade flows to influence prices in countries that trade with each other intensively. Of course, we would not deny that inflation is ultimately a monetary phenomenon, but within the framework of our 5-year rolling horizon, the effects of differences in monetary policy may be hard to discern. The similarity in the cointegration of prices and the money supply of the recent EU members and of the transition economies with the EU core, suggests that relatively stable exchange rate arrangements between the transition-economy candidates and the Euro are possible.

However possible relatively fixed exchange rates against the Euro might be for the transition economies, our analysis of the cointegration of industrial production suggests that the candidate countries do not exhibit very strong cointegration of real output, and this 
generalization holds even when we take into account the relatively weak cointegration of the industrial output between the recent EU members and Germany and France. This result implies that, while a close link to the Euro is feasible upon accession to EU membership, the transition economies would be well advised to retain some measure of policy autonomy to deal with productivity shocks whose magnitude and timing may continue to differ significantly from the shocks affecting the EU core. Finally, the results on industrial production as well as the finding that monetary outcomes in recent EU members and in the transition economies are more closely related to EU developments than is monetary policy suggest that perhaps we should place less emphasis on policy coordination as a means to the economic unification of Europe and more on the flows of goods, capital and productive factors among the EU countries and between them and the candidate countries. 
William Davidson Institute Working Paper 458

\section{Table 1 - Countries and Sample Periods}

\begin{tabular}{|l|l|l|l|l|}
\hline COUNTRY & CPI & MB & M2 & Industrial Output \\
\hline EU COUNTRIES & & & & \\
\hline GERMANY & $80: 01-01: 04$ & $80: 01-01: 04$ & $80: 01-01: 04$ & $80: 01-01: 04$ \\
FRANCE & $80: 01-01: 04$ & $80: 01-01: 04$ & $80: 01-01: 04$ & $80: 01-01: 04$ \\
AUSTRIA & $80: 01-01: 04$ & $83: 05-98: 03$ & $88: 08-98: 02$ & $80: 01-01: 04$ \\
DENMARK & $80: 01-01: 04$ & $80: 01-01: 04$ & $80: 01-00: 06$ & $80: 01-00: 06$ \\
PORTUGAL & $80: 01-01: 04$ & $80: 01-98: 12$ & $80: 01-98: 12$ & NA \\
SPAIN & $80: 01-01: 04$ & $80: 01-98: 12$ & $80: 01-98: 12$ & $80: 01-01: 04$ \\
SWEDEN & $80: 01-01: 04$ & $80: 01-01: 04$ & $80: 01-00: 12$ & $80: 01-01: 01$ \\
& & & & \\
CANDIDATES & & $93: 01-01: 04$ & $93: 01-01: 04$ & $92: 01-01: 04$ \\
CZECH REPUBLIC & $93: 01-01: 04$ & $92: 07-01: 04$ & $92: 07-01: 04$ & NA \\
ESTONIA & $92: 01-01: 04$ & $93: 06-00: 07$ & $91: 01-00.11$ & $90: 01-01: 04$ \\
HUNGARY & $90: 01-01: 04$ & $90: 01-01: 04$ & $90: 01-01: 04$ & NA \\
POLAND & $90: 01-01: 04$ & $91: 12-01: 04$ & $91: 12-01: 04$ & $92: 1-01: 04$ \\
SLOVENIA & $92: 01-01: 04$ & &
\end{tabular}

Source: IMF, International Financial Statistics was used to construct the data except for Hungarian M2 data, which were provided by the National Bank of Hungary. The following abbreviations and IMF line numbers are used:

$\mathrm{CPI}=$ consumer price index (line 64)

$\mathrm{MB}=$ monetary base (line 14) - except for France where it is the sum of currency in circulation and reserves $\mathrm{M} 2=$ broader money $=\mathrm{M} 1$ plus quasi deposits (line 35)

Industrial output $=$ industrial production (line 66)

Note: To extend the data to cover the years from 1999 onward, we updated MB data for Germany and France by using (1) Total reserves excluding Gold till 2001 in each country and (2) an estimate of currency in circulation (CIC), which was proxied by the growth rates of "Euro Area" CCI for the 99-01 period. In other words, we assumed that German and French MB would grow at the same rate as the Euro area CIC, since individual country data for Germany and France are not available after 98:12. 


\section{REFERENCES}

Bayoumi, Tamim and Eichengreen, Barry, "Shocking Aspects of European Monetary Integration." In Francisco Torres and Fracesco Giavazzi (eds.), Growth and Adjustment in the European Monetary Union. Oxford: Cambridge University Press (1993)

Begg, David, "Pegging Out: Lessons from the Czech Exchange Rate Crisis". Journal of Comparative Economics, Vol. 26, No.4, ( December, 1998), pp. 669-690.

Brada, Josef C., and Kutan, Ali M., "The Convergence of Monetary Policy between Candidate Countries and the European Union". Economic Systems, Vol. 25, No.3, (Sept. 2001), pp. 215-231.

Estrin, Saul, Urga, Giovanni, and Lazarova, Stepana, "Testing for Ongoing Convergence in Transition Economies, 1970 to 1998". Journal of Comparative Economics, Vol. 29, No.4 (Dec. 2001), pp. 677-691.

Giersbergen, N. P. A. van ,"Bootstrapping the Trace Statistic in VAR Models: Monte Carlo Results and Applications." Oxford Bulletin of Economics and Statistics, Vol. 58, (1996) pp. 391-408.

Hansen, Henrik, and Johansen, Søren, "Some Tests for Parameter Constancy in Cointegrated -VAR Models." Econometrics Journal, Vol. 2, (1999), pp. 306-33.

Janáčková, Stanislava, "Price Convergence and the Readiness of the Czech Economy for Accession to the European Union". Eastern European Economics, Vol. 38, No. 4, (JulyAugust, 2000), pp. 73-91.

Johansen, Søren, "Statistical Analysis of Cointegration Vectors." Journal of Economic Dynamics and Control, Vol. 12, (1988), pp. 231-254.

Johansen, Søren, "Estimation and Hypothesis Testing of Cointegration Vectors in Gaussian Vector Autoregressive Models." Econometrica, Vol. 59, (1991), pp. 1551-1580.

Johansen, Søren and Katarina Juselius, , "Maximum Likelihood Estimation and Inference on Cointegration - With Applications to the Demand for Money." Oxford Bulletin of Economics and Statistics, Vol. 52, (1990), pp. 169-210.

Kirschgössner, Gebhard and Wolters, Jürgen, "Does the DM Dominate the Euro Market? An Empirical Investigation." Review of Economics and Statistics, Vol. 75, No.4, (November, 1993), pp. 773-778.

Kočenda, Evžen, "Macroeconomic Convergence in Transition Economies". Journal of Comparative Economics, Vol. 29, No. 1 (March, 2001), pp. 1-23.

Korhonen, Iikka and Fidrmuc, Jarko, "Similarity of Supply and Demand Shocks Between the Euro Area and the Accession Countries." Focus on Transition, No 2., (2001), pp.26-42. 
McKinnon, Ronald I., "Toward Virtual Exchange-Rate Stability in Western and Eastern Europe with the Advent of EMU." In Mario I. Blejer and Marko Skreb (eds.), Balance of Payments, Exchange Rates, and Competitiveness In Transition Economies. Boston: Kluwer, (1999), pp. 131-158.

Mundell, Robert, "A Theory of Optimum Currency Areas." American Economic Review, Vol. LI, No. 4, (1961), pp. 657-665.

Osterwald-Lenum, Michael, "A Note with Quantiles of the Asymptotic Distribution of the Maximum Likelihood Cointegration Rank Test Statistics." Oxford Bulletin of Economics and Statistics, Vol. 54, (1992), pp. 461-472.

Rangvid, Jesper, and Sørensen, Carsten, "Convergence in the ERM and Declining Numbers of Common Stochastic Trends" . Department of Finance, Copenhagen Business School, November, 2000.

Reinsel, G. C., and Ahn, S. K., "Vector Autoregressive Models with Unit Roots and Reduced Rank Structure: Estimation, Likelihood Ratio Test, and Forecasting." Journal of Time Series Analysis, Vol. 13, (1992), pp. 353-75.

Richards, Anthony J. and Tersman, Gunnar H. R., "Growth, Nontadables, and Price Convergence in the Baltics." Journal of Comparative Economics, Vol. 23, No 2, (October, 1996), pp. 121-145.

von Hagen, Jürgen and Fratianni, Michele, "German Dominance in the EMS: Evidence from Interest Rates.” Journal of International Money and Finance, Vol. 9, No. 4, (December, 1990), pp. 358-375. 


\section{Figure 1 - Rolling Test of Cointegration of Base Money}

\section{between:}

\section{Germany and Recent EU Members}

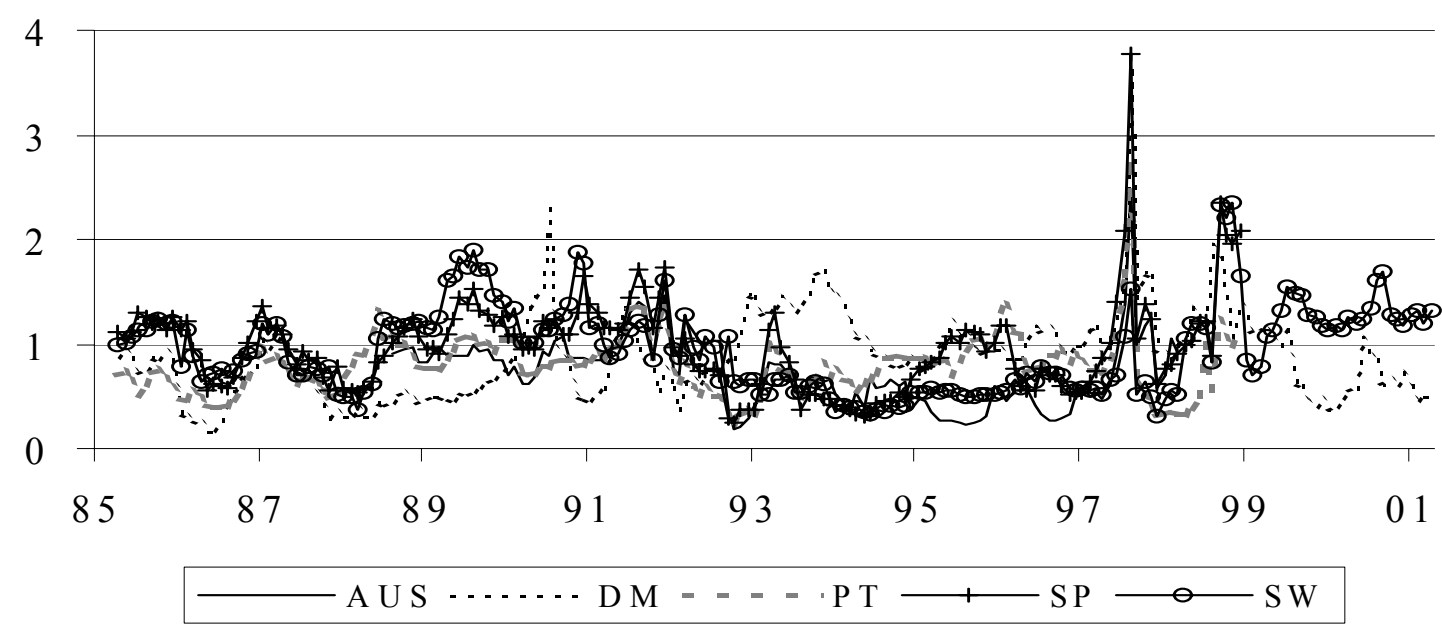

France and Recent EU Members

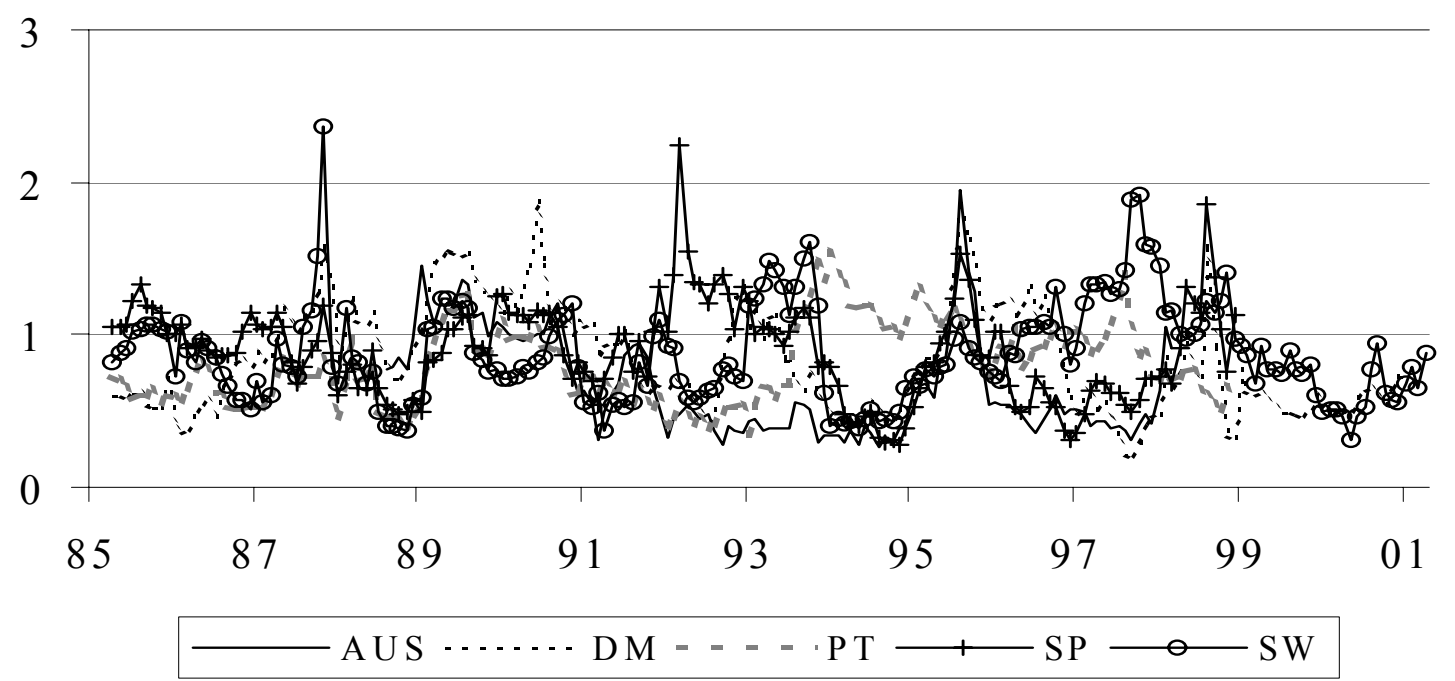

Note: The vertical axis in Figures 1-4 shows the value of the test statistic for the null hypothesis of no cointegration between the two series scaled by the critical value at the $10 \%$ significance level. A series value greater than 1 means that we can reject the hypothesis of no cointegration at a $10 \%$ significance level; a value above 2 allows rejection of the hypothesis at a better than $1 \%$ significance level. 
Figure 1 Base Money - continued

\section{Germany and EU C andidates}

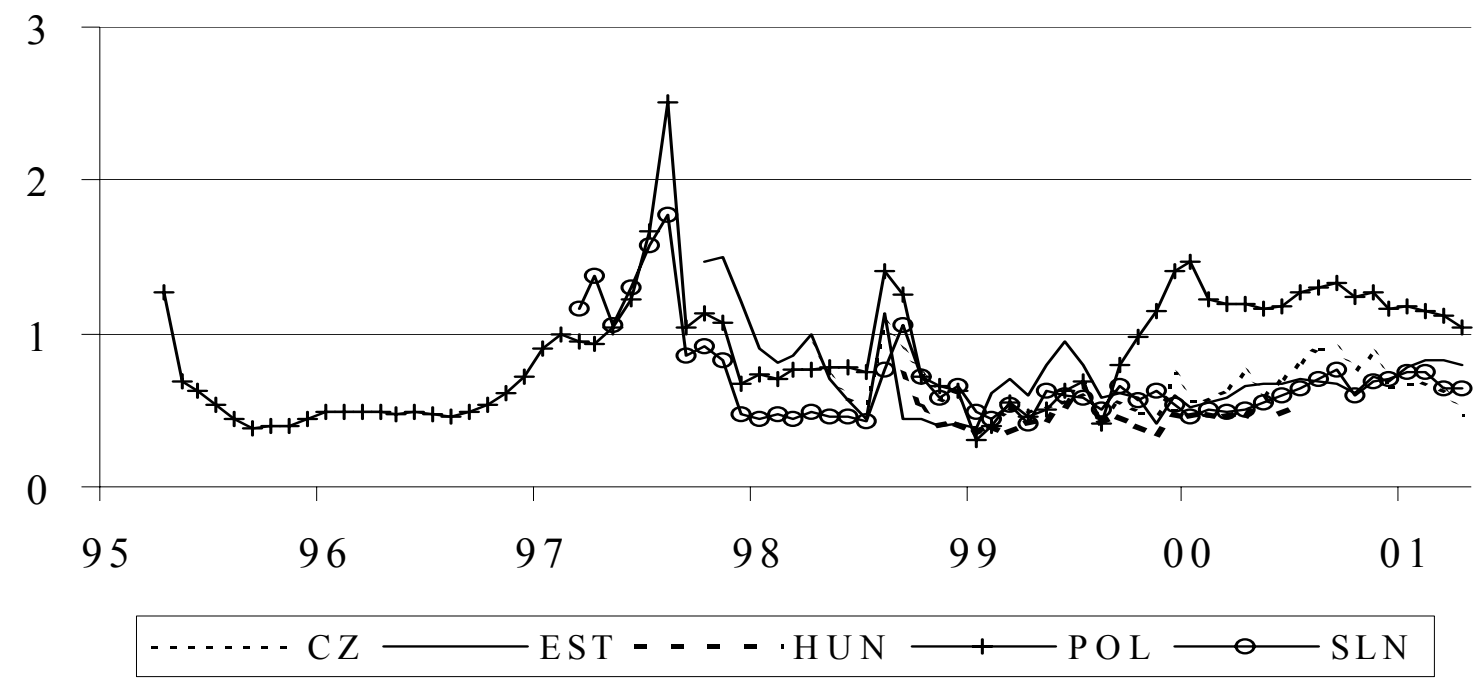

France and EU Candidates

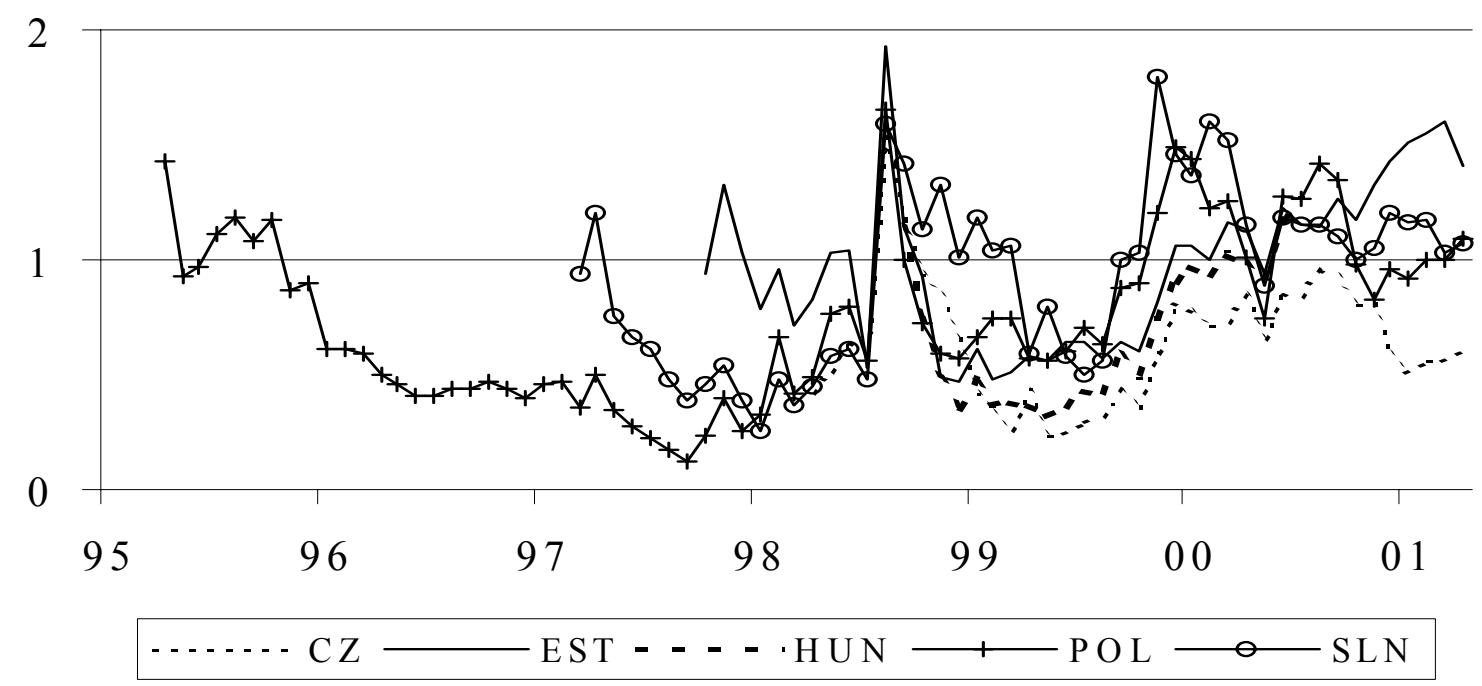




\section{Figure 2 - Rolling Test of Cointegration of M2 between:}

\section{Germany and Recent EU Members}

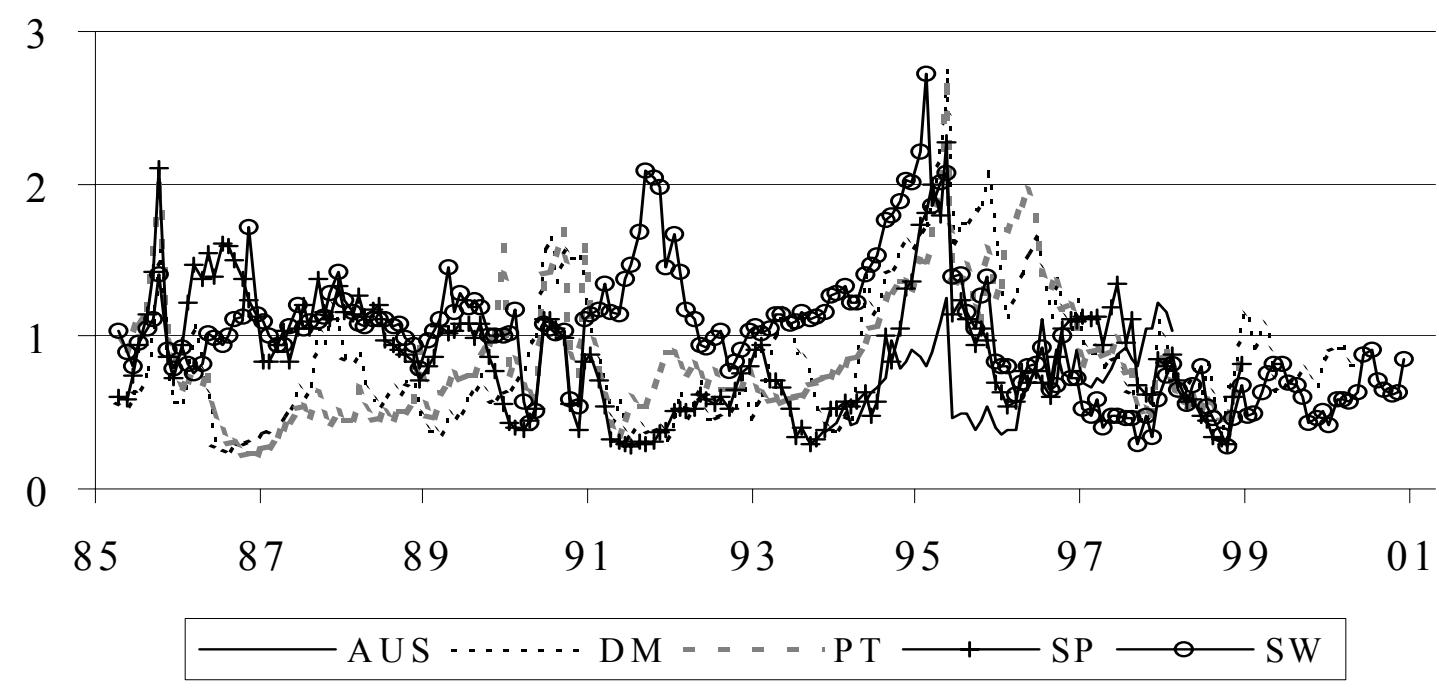

France and Recent EU Members

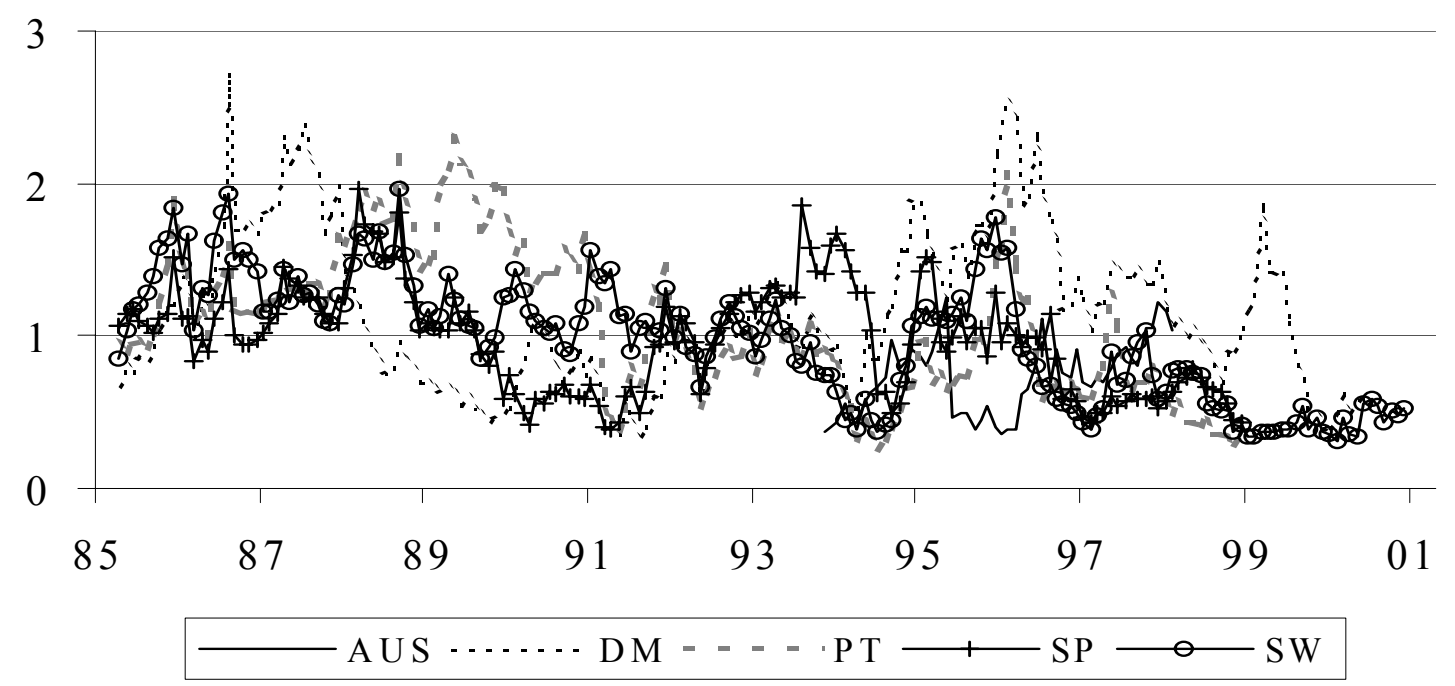

11 
Figure 2 M2 - continued

\section{Germany and EU Candidates}

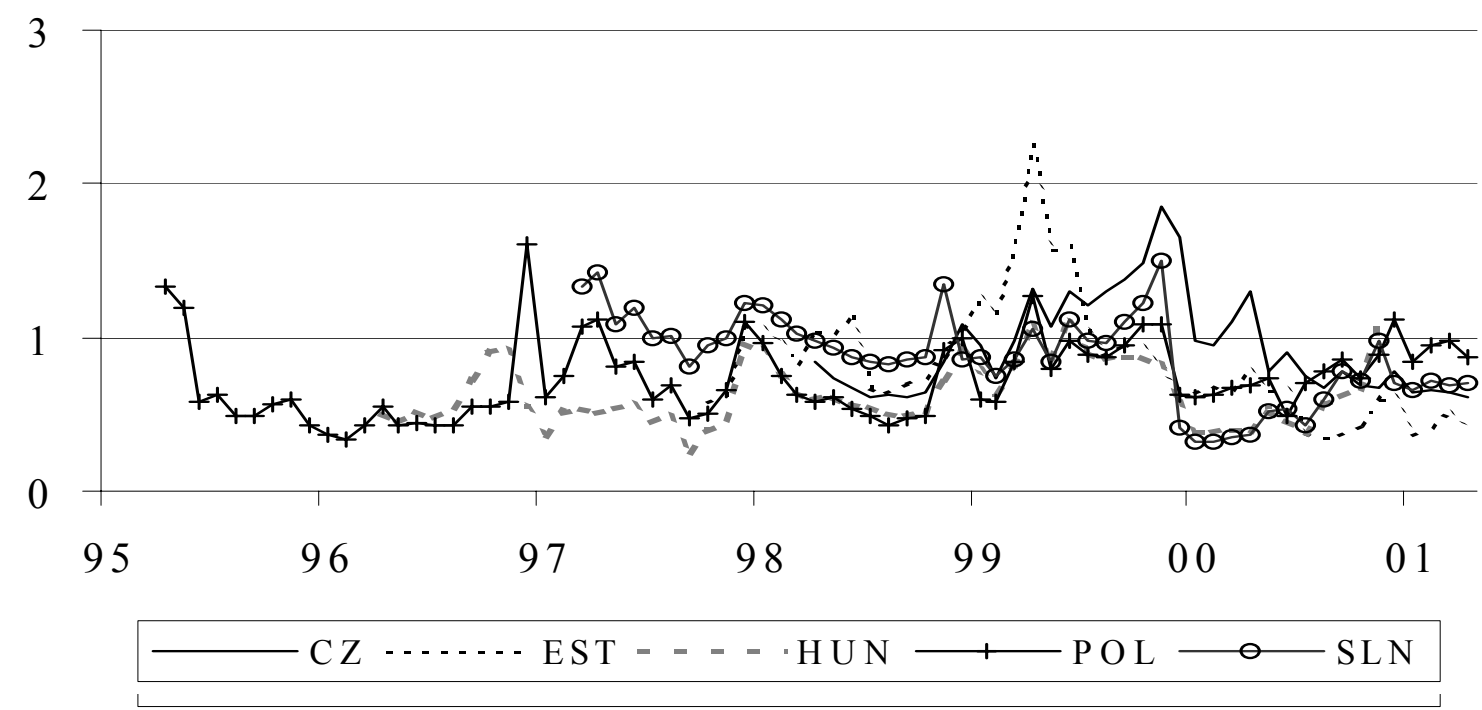

France and EU C andidates

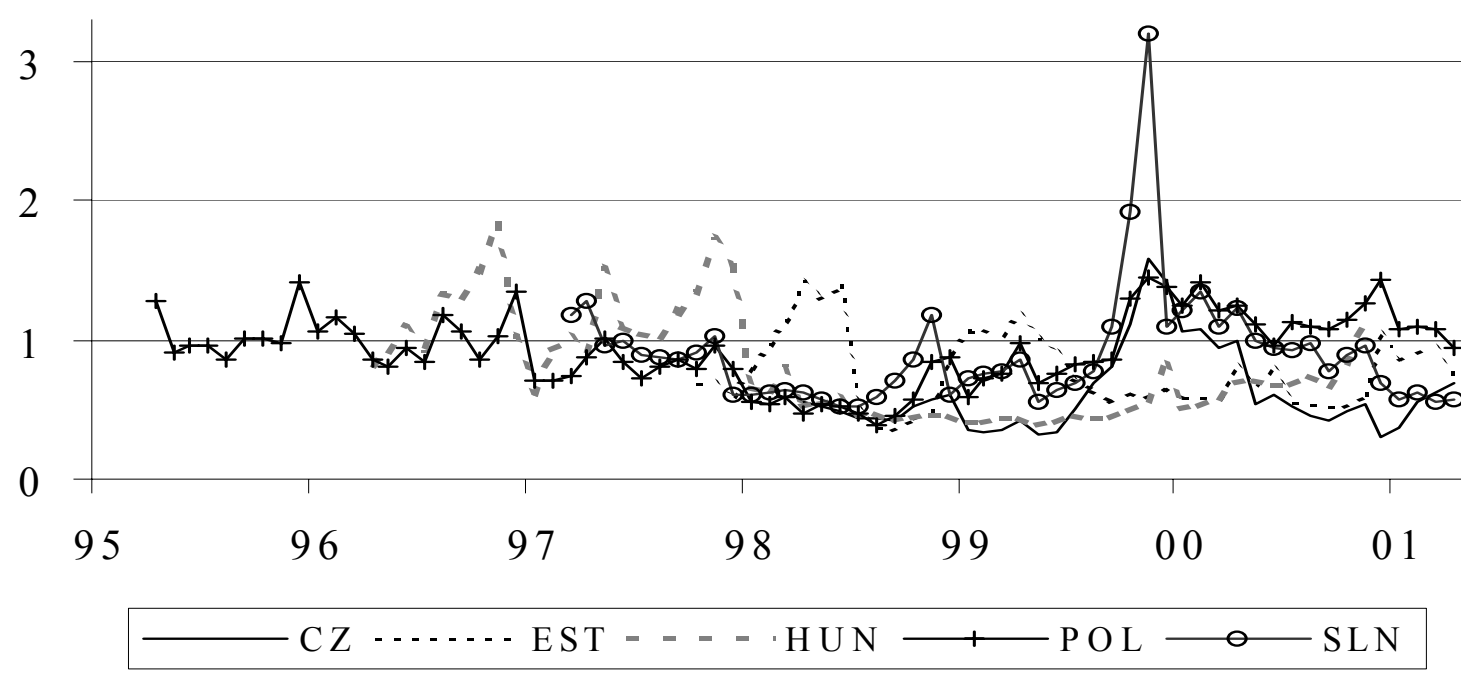

Note: The vertical axis in Figures 1-4 shows the value of the test statistic for the null hypothesis of no cointegration between the two series scaled by the critical value at the $10 \%$ significance level. A series value greater than 1 means that we can reject the hypothesis of no cointegration at a $10 \%$ significance level; a value above 2 allows rejection of the hypothesis at a better than $1 \%$ significance level. 


\section{Figure 3 - Rolling Test of Cointegration of CPI between:}

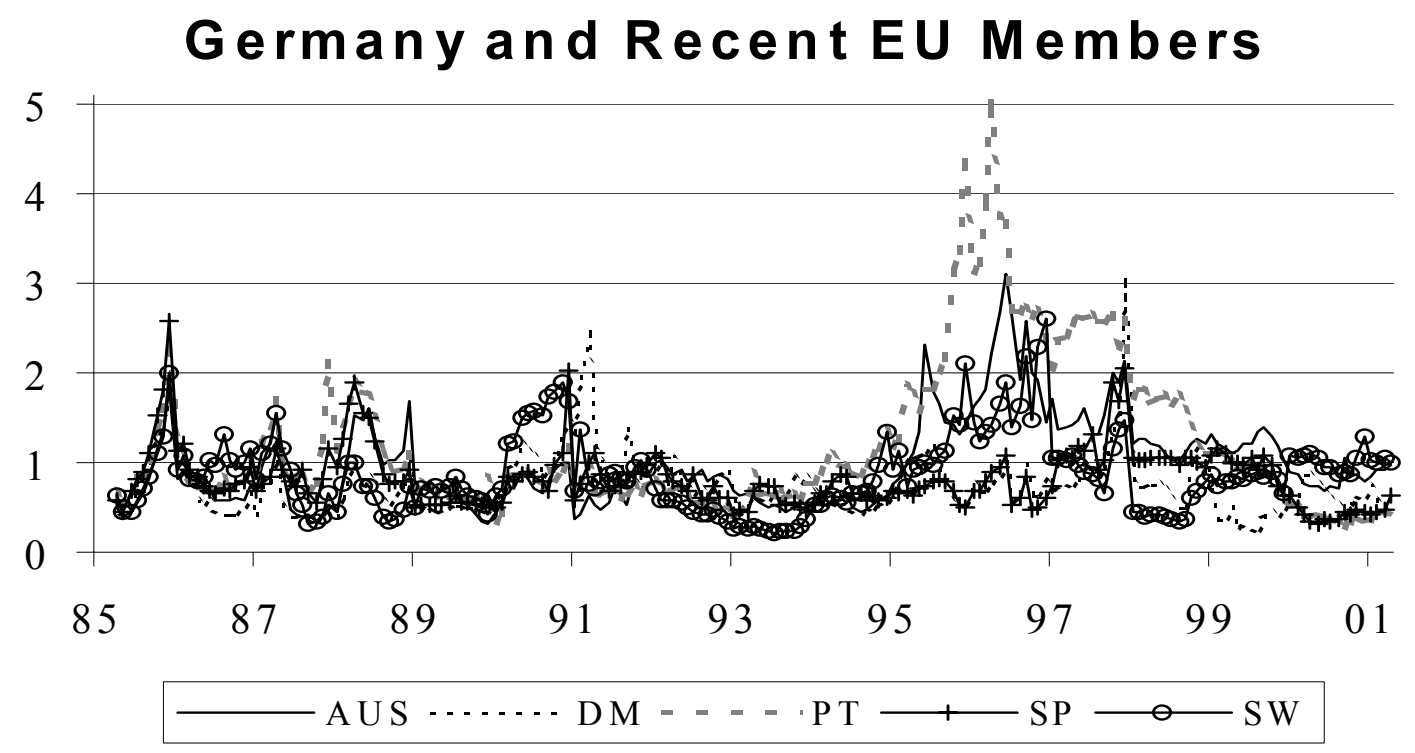

France and Recent EU Members

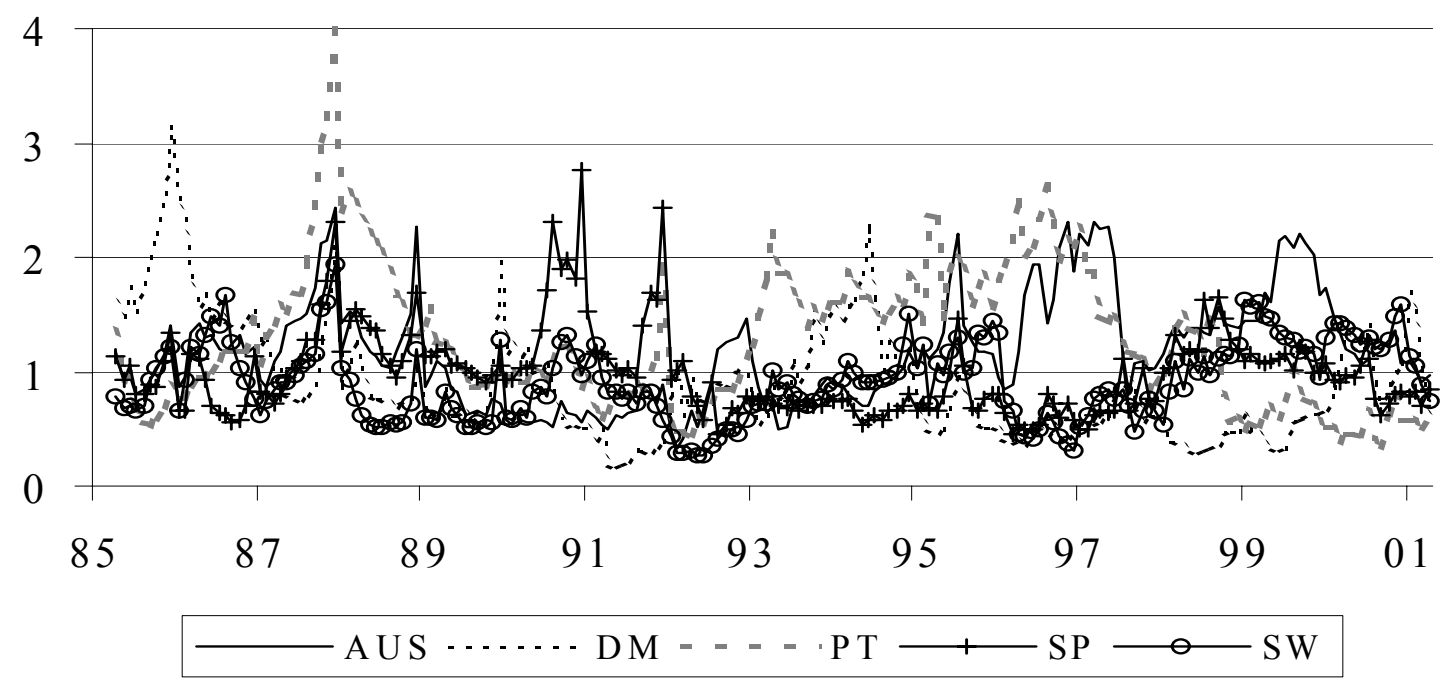


Figure $3 \mathrm{CPI}$ - Continued

\section{Germany and EU Candidates}

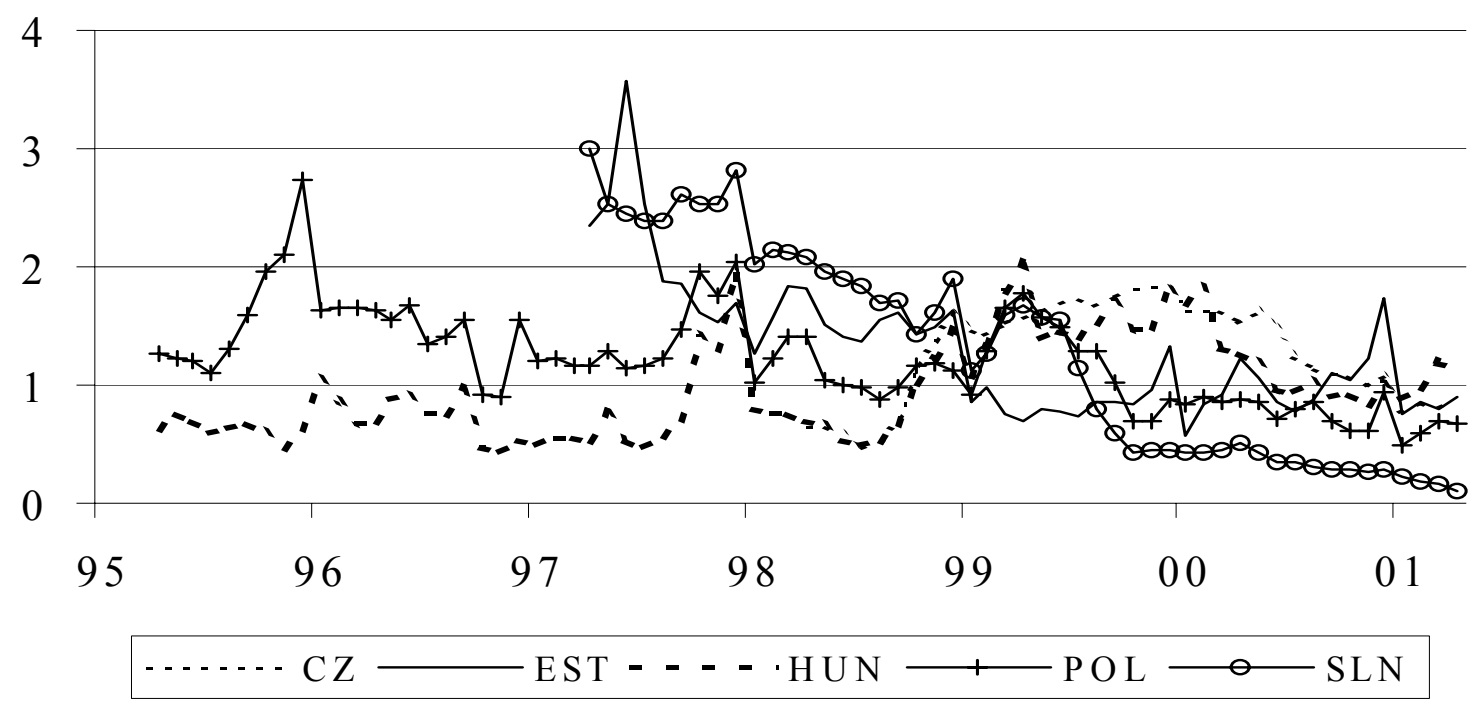

France and EU Candidates

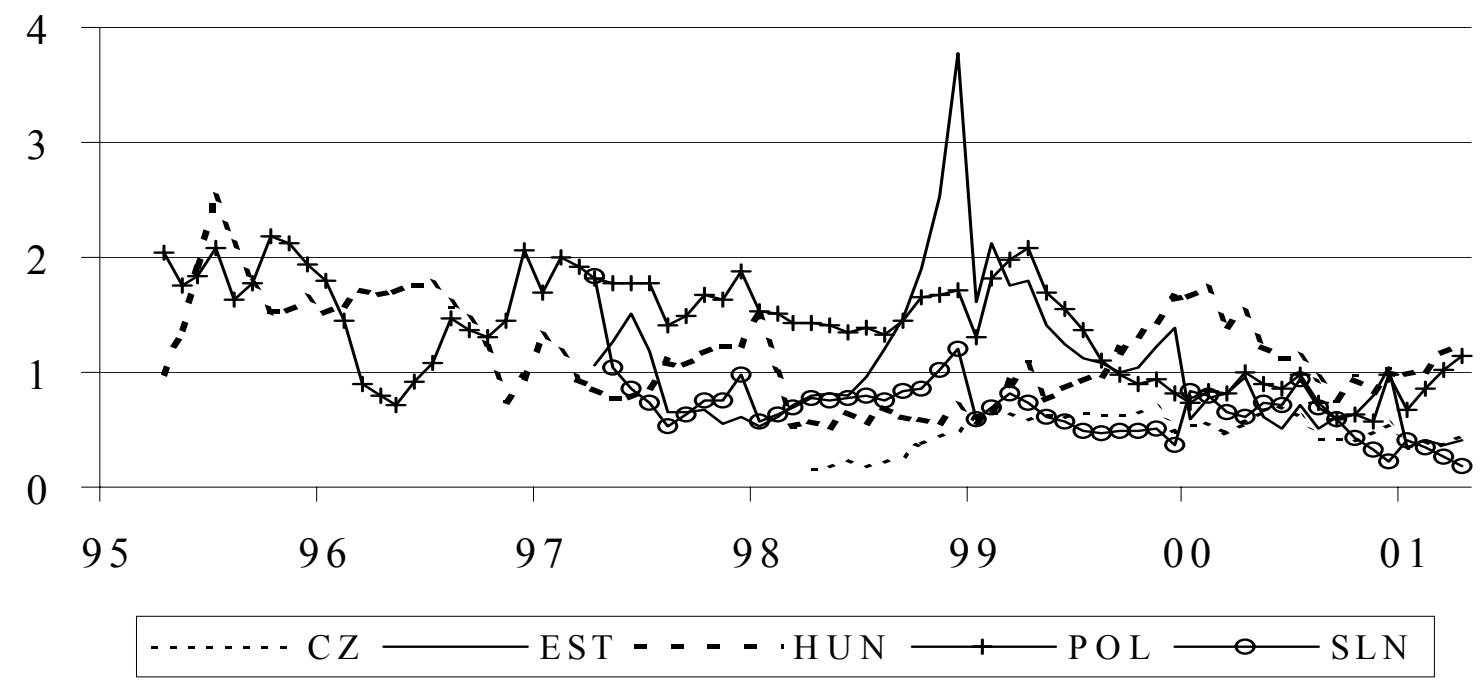

Note: The vertical axis in Figures 1-4 shows the value of the test statistic for the null hypothesis of no cointegration between the two series scaled by the critical value at the $10 \%$ significance level. A series value greater than 1 means that we can reject the hypothesis of no cointegration at a $10 \%$ significance level; a value above 2 allows rejection of the hypothesis at a better than $1 \%$ significance level. 
Figure 4 - Rolling Test of Cointegration of Industrial Production between:

Germany and Recent EU Members

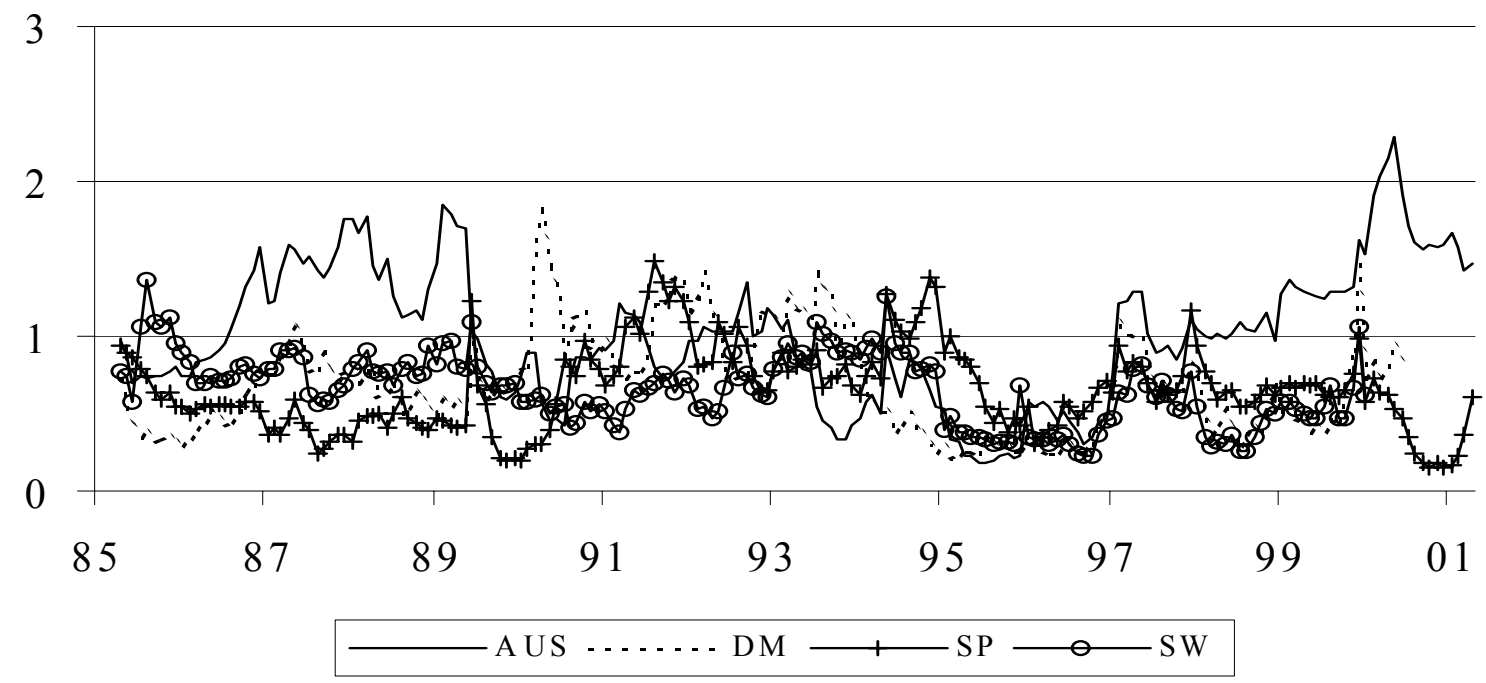

France and Recent EU Members

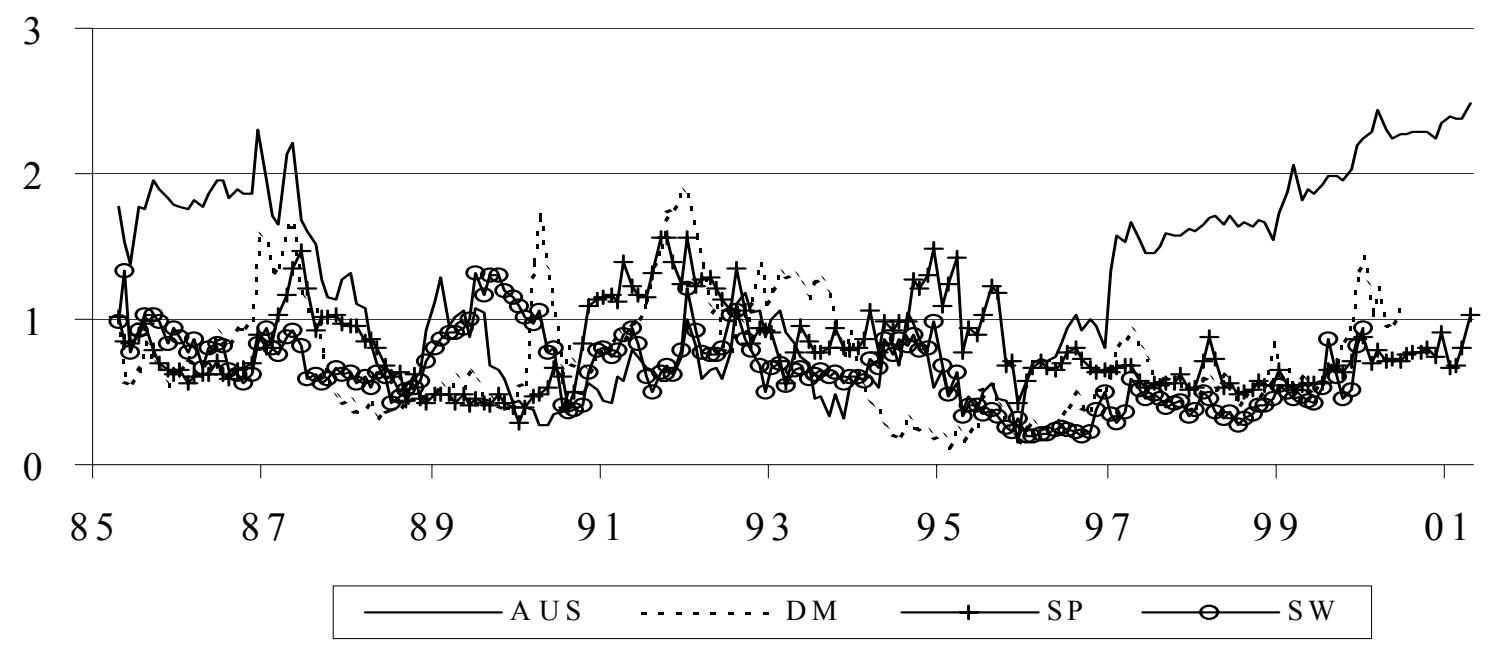


Figure 4 Ind. Prod. - continued

\section{Germany and EU Candidates}

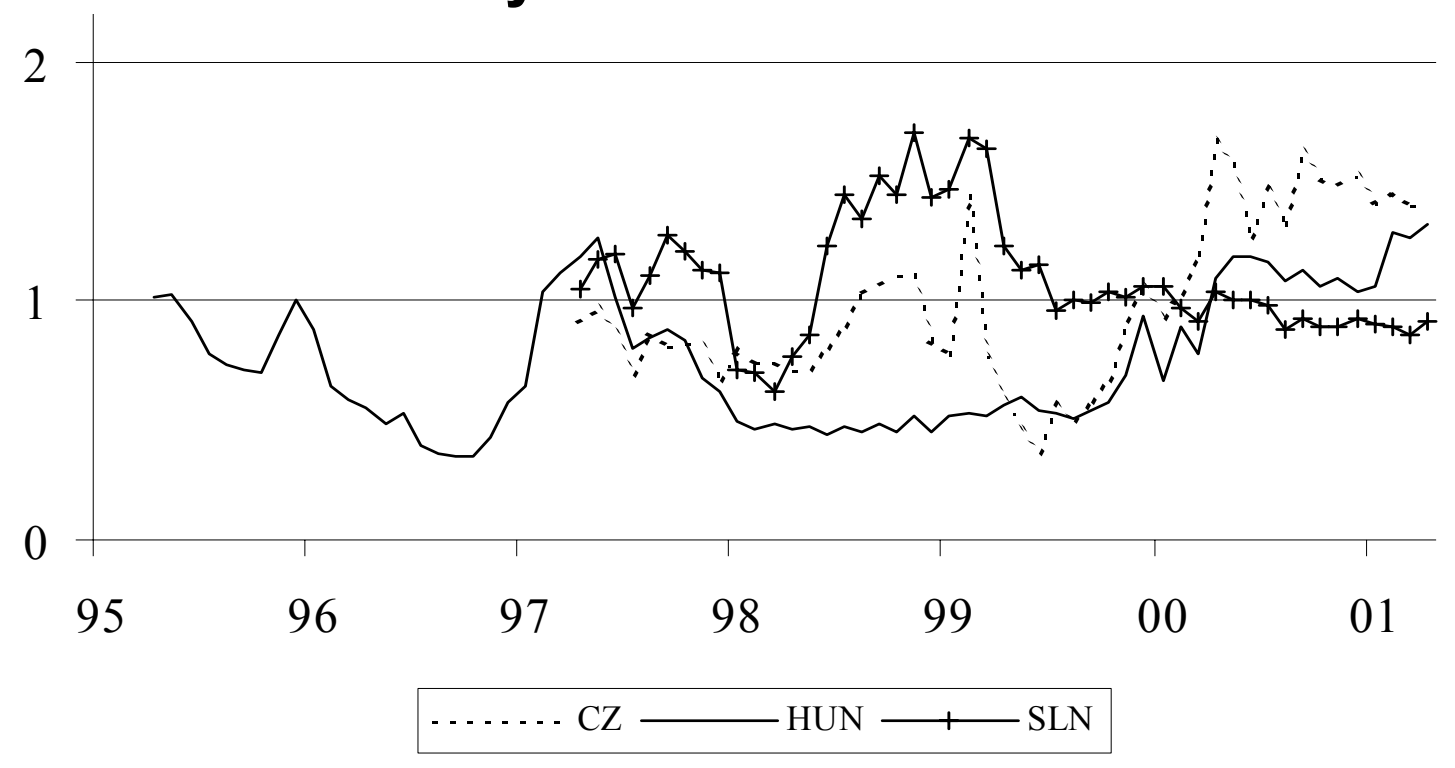

France and EU Candidates

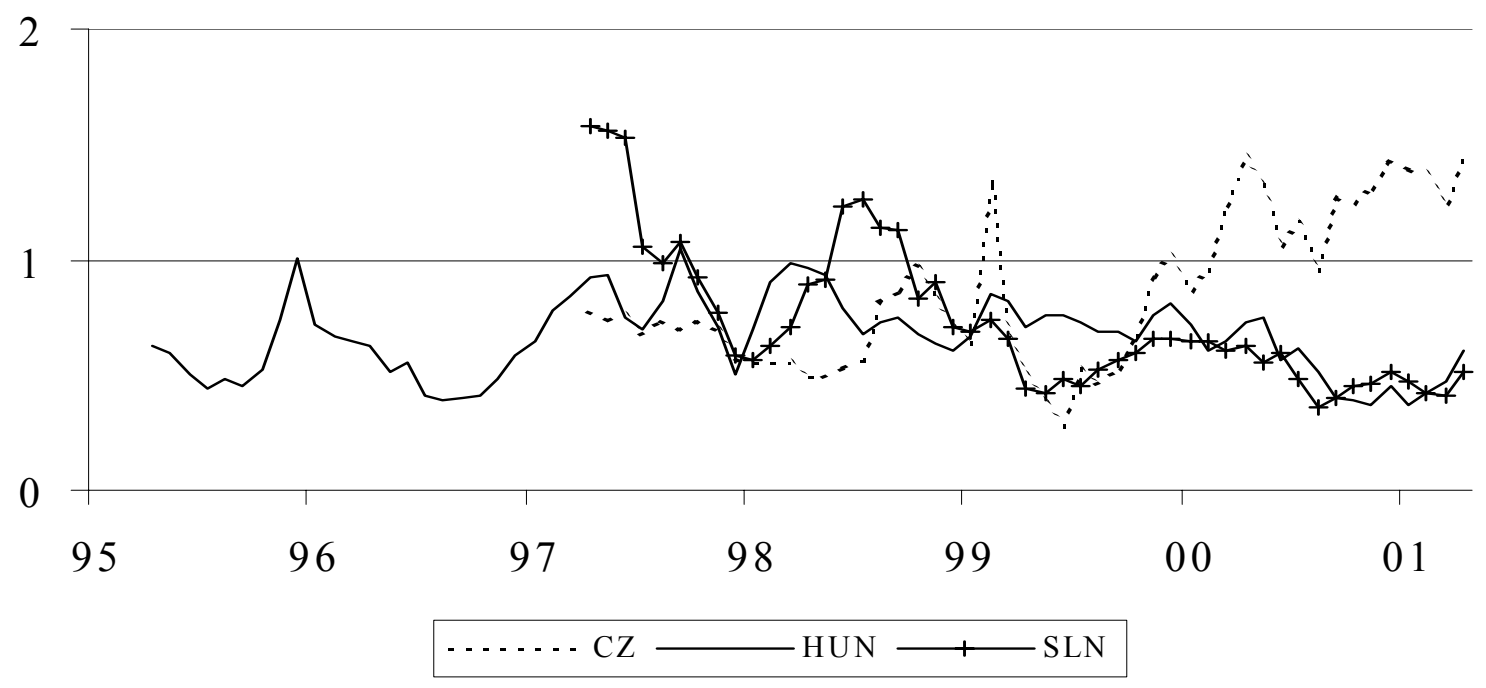




\section{DAVIDSON INSTITUTE WORKING PAPER SERIES - Most Recent Papers}

The entire Working Paper Series may be downloaded free of charge at: www.wdi.bus.umich.edu

CURRENT AS 4/9/02

\begin{tabular}{|c|c|c|}
\hline Publication & Authors & Date \\
\hline $\begin{array}{l}\text { No. 458: Real and Monetary Convergence within the European Union } \\
\text { and Between the European Union and Candidate Countries: } \\
\text { A Rolling Cointegration Approach }\end{array}$ & $\begin{array}{l}\text { Josef C. Brada, Ali M. Kutan and } \\
\text { Su Zhou }\end{array}$ & Apr. 2002 \\
\hline No. 457: Credit Ratings as Coordination Mechanisms & $\begin{array}{l}\text { Arnoud W. A. Boot and Todd T. } \\
\text { Milbourn }\end{array}$ & Mar. 2002 \\
\hline $\begin{array}{l}\text { No. 456: Balkan and Mediterranean Candidates for European Union } \\
\text { Membership: The Convergence of their Monetary Policy with that of the } \\
\text { European Central Bank }\end{array}$ & Josef C. Brada and Ali M. Kutan & Apr. 2002 \\
\hline $\begin{array}{l}\text { No. 455: Russian Financial Transition: The Development of Institutions } \\
\text { and Markets for Growth }\end{array}$ & David M. Kemme & Oct. 2001 \\
\hline $\begin{array}{l}\text { No. 454: Does the Market Pay Off? Earnings Inequality and Returns to } \\
\text { Education in Urban China }\end{array}$ & Xiaogang $\mathrm{Wu}$ and $\mathrm{Yu} \mathrm{Xie}$ & Apr. 2002 \\
\hline $\begin{array}{l}\text { No. 453: Entrepreneurs' Access to Private Equity in China: } \\
\text { The Role of Social Capital }\end{array}$ & Bat Batjargal and Mannie M. Liu & Apr. 2002 \\
\hline $\begin{array}{l}\text { No. 452: The Determinants of Privatised Enterprise Performance in } \\
\text { Russia }\end{array}$ & $\begin{array}{l}\text { Alan A. Bevan, Saul Estrin, Boris } \\
\text { Kuznetsov, Mark E. Schaffer, } \\
\text { Manuela Angelucci, Julian } \\
\text { Fennema and Giovanni } \\
\text { Mangiarotti }\end{array}$ & June 2001 \\
\hline $\begin{array}{l}\text { No. 451: Determinants of Finan } \\
\text { in a Transition Economy? The C }\end{array}$ & Lubomír Lízal & Jan. 2002 \\
\hline No. 450: Corporate Governance and the Global Social Void & ee A. Tavis & Oct. 2001 \\
\hline $\begin{array}{l}\text { No. 449: Financial Architecture and Economic Performance: } \\
\text { International Evidence }\end{array}$ & Solomon Tadesse & Aug. 2001 \\
\hline $\begin{array}{l}\text { No. 448: Growth Slowdown Under Central Planning: A Model of Poor } \\
\text { Incentives }\end{array}$ & Zuzana Brixiová and Aleš Bulíř & Mar. 2002 \\
\hline $\begin{array}{l}\text { No. 447: Disentangling Treatment Effects of Polish Active Labor } \\
\text { Market Policies: Evidence from Matched Samples }\end{array}$ & $\begin{array}{l}\text { Jochen Kluve, Hartmut Lehmann, } \\
\text { and Christoph M. Schmidt }\end{array}$ & Jan. 2002 \\
\hline $\begin{array}{l}\text { No. 446: The Impact of Socialist Imprinting and Search for Knowledge } \\
\text { on Resource Change: An Empirical Study of Firms in Lithuania }\end{array}$ & $\begin{array}{l}\text { Aldas Kriauciunas and Prashant } \\
\text { Kale }\end{array}$ & Mar. 2002 \\
\hline $\begin{array}{l}\text { No. 445: The Costs, Wealth Effects, and Determinants of International } \\
\text { Capital Raising: Evidence from Public Yankee Bonds }\end{array}$ & $\begin{array}{l}\text { Darius P. Miller and John J. } \\
\text { Puthenpurackal }\end{array}$ & Oct. 2001 \\
\hline No. 444: Financial Institutions, Contagious Risks, and Financial Crises & $\begin{array}{l}\text { Haizhou Huang and Chenggang } \\
\mathrm{Xu}\end{array}$ & Nov. 2001 \\
\hline No. 443: Banks as Catalysts for Industrialization & $\begin{array}{l}\text { Marco Da Rin and Thomas } \\
\text { Hellmann }\end{array}$ & Oct. 2001 \\
\hline $\begin{array}{l}\text { No. 442: Bank-Based or Market-Based Financial Systems: Which is } \\
\text { Better? }\end{array}$ & Ross Levine & Feb. 2002 \\
\hline $\begin{array}{l}\text { No. 441: Migration and Regional Adjustment and Asymmetric Shocks } \\
\text { in Transition Economies }\end{array}$ & Jan Fidrmuc & Feb. 2002 \\
\hline $\begin{array}{l}\text { No. 440: Employment and Wages in Enterprises Under Communism } \\
\text { and in Transition: Evidence From Central Europe and Russia }\end{array}$ & $\begin{array}{l}\text { Swati Basu, Saul Estrin, and Jan } \\
\text { Svejnar }\end{array}$ & June 2000 \\
\hline No. 439: Small business in Russia: A Case Study of St. Petersburg & Alessandro Kihlgren & Jan. 2002 \\
\hline $\begin{array}{l}\text { No. 438: Foreign Direct Investment as Technology Transferred: } \\
\text { Some Panel Evidence from the Transition Economies }\end{array}$ & $\begin{array}{l}\text { Nauro F. Campos and Yuko } \\
\text { Kinoshita }\end{array}$ & Jan. 2002 \\
\hline No. 437: Whistleblowing, MNC's and Peace & Terry Morehead Dworkin & Feb. 2002 \\
\hline $\begin{array}{l}\text { No. 436: A Note on Measuring the Unofficial Economy in the Former } \\
\text { Soviet Republics }\end{array}$ & $\begin{array}{l}\text { Michael Alexeev and William } \\
\text { Pyle }\end{array}$ & Sept. 2001 \\
\hline $\begin{array}{l}\text { No. 435: The Ownership School vs. the Management School of State } \\
\text { Enterprise Reform: Evidence from China }\end{array}$ & David D. Li and Changqi Wu & Jan. 2002 \\
\hline
\end{tabular}

